\title{
Papaya Fruit Growth, Calcium Uptake, and Fruit Ripening
}

\author{
Yunxia Qiu', Melvin S. Nishina', and Robert E. Paull ${ }^{3}$ \\ University of Hawaii at Manoa, 3190 Maile Way Honolulu, HI 96822
}

\begin{abstract}
The uptake of Ca by 'Sunset' papaya (Carica papaya L.) fruit and its role in ripening was studied. The highest mesocarp Ca uptake rate occurred in fruit that were $<40$ days postanthesis when fruit transpiration was probably highest. Ca uptake rate by the mesocarp was low, from 60 to 80 days postanthesis when fruit fresh and dry weight increased. Mesocarp Ca uptake rate increased again from 100 to 140 days postanthesis when fruit fresh weight growth rate declined and dry weight growth rate increased. Mesocarp Ca concentration did not significantly differ from the peduncle to the blossom end. although Ca was significantly higher in the outer than inner mesocarp at the fruit equator. Mesocarp Ca

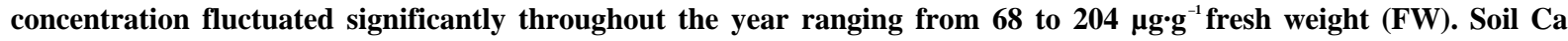
application did not always increase fruit mesocarp Ca concentration, while $\mathrm{K}$ and $\mathrm{N}$ fertilization decreased mesocarp $\mathrm{Ca}$ concentration. Attempts to increase mesocarp $\mathrm{Ca}$ concentration by spraying $\mathrm{CaCl}_{2}$ onto papaya fruit during growth and by postharvest vacuum infiltration and dipping of the cut peduncle into $\mathrm{CaCl}_{2}$ were unsuccessful. Mesocarp Ca concentration was positively correlated to the firmness of ripe papaya fruit and the rate of softening of mesocarp plugs. Less correlation was found between fruit firmness and the ratio of Ca concentration to $\mathrm{K}$ or $\mathrm{Mg}$ concentration, or to $\mathrm{Mg}$ plus $\mathrm{K}$ concentrations. Mesocarp Ca concentration of $130 \mu \mathrm{g} \cdot \mathrm{g}^{-1} \mathrm{FW}$ or above was associated with slower fruit softening rate than fruit with a lower concentration.
\end{abstract}

Increased fruit $\mathrm{Ca}$ levels delay softening and maintain quality in apple (Conway and Sams, 1987: Poovaiah, 1986), tomato (Rigney and Wills. 1981). and avocado (Eaks. 1985). Physiological disorders associated with inadequate Ca levels occur in many plants (Bangerth, 1979). Inadequate Ca often occurs in those plant parts that are naturally low in $\mathrm{Ca}$, such as fruit and storage organs (Bangerth, 1979). The best known disorders in fruit are bitter pit of apple (Ferguson and Watkins. 1989) and blossom end rot of tomatoes (Evans and Troxler, 1953). Treatment of mangoes (Tirmazi and Wills. 198 I ). pears and bananas (Wills et al.. 1982). sweet cherry (Facteau et al.. 1987), and strawberry (Cheour et al.. 1991) delay fruit ripening and senescence.

Inspected shipments of Hawaii papaya fruit in the New York market had overripe and abnormally soft fruit (Cappellini et al., 1988). Sporadically. commercial papaya-packing sheds in Hawaii have also reported batches of fruit that ripened very rapidly. This soft fruit disorder leads to disruption of marketing and higher losses. The inability to predict the occurrence of this disorder limits the range of options available to deal with this problem. Initial results suggest that low fruit Ca may be related to the problem (Paull, 1987). The objective of this study was to determine the uptake of Ca by papaya fruit and the role of $\mathrm{Ca}$ in papaya fruit ripening.

\section{Materials and Methods}

Plant materials. 'Sunset' papaya fruit grown at Poamoho

\footnotetext{
Received for publication 28 Mar. 1994. Accepted for publication 14 Oct. 1994. Hawaii Institute of Tropical Agriculture and Human Resources Journal series no. 3977. We express our appreciation for the technical assistance provided by Gail Uruu and Ted Goo. Mention of a trademark or proprietary product does not constitute a guarantee or warranty of a product by the Univ. of Hawaii and does not imply its approval to the exclusion of other products that may also be suitable. This research was supported by USDA-CSRS special grant program in tropical and subtropical agriculture 90-34222-5320. The cost of publishing this paper was defrayed in part by the payment of page charges. Under postal regulations, this paper therefore must be hereby marked advertisement solely to indicate this fact. 'Graduate student. Dept. of Plant Molecular Physiology.

${ }^{2}$ Extension agent. College of Tropical Agriculture and Human Resources Cooperative Extension Service.

${ }^{3}$ Professor. Dept. of Plant Molecular Physiology. To whom reprint requests should be addressed
}

Experiment Station, central Oahu, were used for preharvest $\mathrm{CaCl}_{2}$ spray and postharvest $\mathrm{CaCl}_{2}$ dip treatments. The commercial variety 'Kapoho Solo' was used for the field fertilization experiment on the Island of Hawaii. The fruit were harvested and returned to the laboratory in Honolulu on the same day. Fruit were sorted by skin color and stored at $22 \mathrm{C}$ until they reached the desired stage of ripeness.

The skin and mesocarp color were subjectively evaluated by estimating the percent area of yellowing of the fruit surface and of a mesocarp vertical section, respectively. Deformation force was measured with a penetrometer fitted with a $1.6-\mathrm{cm}$-diameter tip pressed $2 \mathrm{~mm}$ into the flesh at the fruit equator.

Fruit from 19-month-old 'Sunset' trees were harvested to determine the uptake patterns of $\mathrm{Ca}, \mathrm{Mg}$, and $\mathrm{K}$ by fruit of different maturities. Two to three phyllotaxic spirals can exist on a papaya tree, and three trees having two spirals each were used in this study. Fruit from each tree was divided into two groups based on the phyllotaxic position on the spiral. Fruit number was marked according to the leaf number starting from the apex. Fruit maturity was determined by dividing the days after anthesis from tagged fruit on companion trees by the leaf number. The fruit were weighed and the volume was measured by water displacement. Fruit. with -20 days difference in maturity, were chosen from each spiral on the three trees. Each fruit was divided into skin, mesocarp, and seeds, and fresh weight (FW) determined. Ten grams of the skin and seeds and $20 \mathrm{~g}$ of the mesocarp were dried at $60 \mathrm{C}$ for 7 days to determine dry weight (DW) percentage.

Five mature fruit were used to determine $\mathrm{Ca}, \mathrm{Mg}$, and $\mathrm{K}$ distribution. The fruit was divided into exocarp, mesocarp, endocarp, and seeds. The equatorial mesocarp was further divided horizontally into outer and inner tissue. The mesocarp was also divided transversely into peduncle, equatorial and blossom end tissue. The tissues were stored at $-20 \mathrm{C}$ until analyzed.

Fruit surface transpiration was measured with a LI-COR model LI-700 transient automatic diffusion porometer (Paull and Chen, 1989). The time taken (seconds) to cycle through the $35 \%$ to $55 \%$ range was used to determine fruit water diffusive resistance $\left(\mathrm{s} \cdot \mathrm{cm}^{-1}\right)$.

Analysis of $\mathrm{Ca}, \mathrm{Mg}$, and $\mathrm{K}$. For young fruit, the whole fruit was used. Otherwise, $10 \mathrm{~g} \mathrm{FW}$ of skin or seeds and $50 \mathrm{~g}$ mesocarp was used. Tissue was homogenized in a blender with $100 \mathrm{ml}$ deionized 
water. An aliquot $(10 \mathrm{ml})$ was mixed with an equal volume of 12 $\mathbf{M ~ H C l}$ and heated at $60 \mathrm{C}$ for $30 \mathrm{~min}$. The solution was filtered through a Whatman \#42 ashless filter paper into a 50-ml volumetric flask and made up to the volume with deionized water. For $\mathrm{Ca}$ and $\mathrm{Mg}$ determination, lanthanum chloride $(5 \% \mathrm{w} / \mathrm{v} \mathrm{La}, 1 \mathrm{M} \mathrm{HCl})$ was added during further dilution for a final La concentration of $05 \% \mathrm{w} / \mathrm{v}$. Leaf petiole, total $\mathrm{Ca}, \mathrm{Mg}$, and $\mathrm{K}$ concentrations were determined on dry-ashed, ground tissue. Total $\mathrm{Ca}$ and $\mathrm{Mg}$ concentrations were determined by atomic absorption spectroscopy and $\mathrm{K}$ by emission spectroscopy.

Fruit mesocarp and recently matured petiole $\mathrm{N}$ were determined on one occasion during the field trial to confirm that applied fertilizer was increasing tissue content. Total $\mathrm{N}$ of mesocarp and leaf petiole was measured as $\mathrm{NH}_{4}-\mathrm{N}$ in the acid digests.

Fertilization and Ca chloride sprays. 'Kapoho Solo' papaya seedlings were transplanted into a commercial field on the Island of Hawaii in November 1987. The soil type belonged to the Papai series of Typic Tropofolists. The five fertilizer treatments were applied in a randomized complete-block design and consisted of control, $\mathrm{Ca}$, Ca plus $\mathrm{K}, \mathrm{K}$, and $\mathrm{N}$. Commercial fertilization rates were used as the control level, and applied to the whole 10.5-ha field including the experimental block. The control rate of fertilizer (14N-14P-14K) was: $6.1 \mathrm{~kg} \cdot \mathrm{ha}^{-1}$ per month in $1988,14.6$ $\mathrm{kg} \cdot \mathrm{ha}^{-1}$ per month in 1989 , and $9.7 \mathrm{~kg} \cdot \mathrm{ha}^{-1}$ per month in 1990 . For the other treatments, extra fertilizer was applied when the trees were 6 months old and had begun to flower. Trees were side dressed with $\mathrm{CaCO}_{3}(48.5 \% \mathrm{CaO})$ at the rate of $192 \mathrm{~g} /$ tree per month, $\mathrm{KCl}\left(61 \% \mathrm{~K}_{2} \mathrm{O}\right)$ at the rate of $197.5 \mathrm{~g} /$ tree per month, and urea $(46 \% \mathrm{~N})$ at the rate of $158.7 \mathrm{~g} /$ tree per month. Monthly harvesting began in September 1989 and fruit were air-shipped on the same day to Honolulu for evaluation. Fruit with color break to $15 \%$ skin yellow were used and stored at $22 \mathrm{C}$ until the skin color of the majority of fruit in the control treatment reached $85 \%$ yellow. Data were collected over 11 months.

The fruit on five trees per treatment were sprayed with 21 of deionized water (control) or $2 \%(\mathrm{w} / \mathrm{v}) \mathrm{CaCl}_{2}$ every 2 weeks and harvested (10\% skin coloring) following six spray applications. Additional fruit were harvested with a knife to leave as long a peduncle as possible, and exposed to a high airflow for $24 \mathrm{~h}$ at $22 \mathrm{C}$ (70\% relative humidity). The fruit peduncle was trimmed and dipped immediately into deionized water or $2 \%(\mathrm{w} / \mathrm{v}) \mathrm{CaCl}_{2}$ solution for an additional $48 \mathrm{~h}$ continuously exposed to airflow. All fruit were stored until those treated with deionized water had $95 \%$ yellow skin color. The experiments were repeated three times.

Tissue plug preparation and measurements. Papaya fruit at colorbreak, $10 \%, 30 \%$, and $50 \%$ skin yellowing were washed with soapy water, rinsed with tap water, and dried. After being wiped with $95 \%$ ethanol, plugs were removed in a laminar flow hood with a sterile 1.4-cm corkborer and sorted by degree of mesocarp color (Qiu, 1992). The skin and endocarp were not removed and the plug was stored in a $15-\mathrm{ml}$ sterile test tube covered with sterile cotton at $22 \mathrm{C}$. Plug firmness was measured by pressing a penetrometer with a O\&cm-diameter tip $1 \mathrm{~cm}$ into mesocarp tissue from the endocarp side toward the skin. The solutions (EGTA, $10 \mathrm{~mm}$; sodium citrate, $50 \mathrm{~mm}$; calcium chloride, $50 \mathrm{~mm}$ ) used for infiltration were prepared in $100 \mathrm{~mm}$ 2-(morpholino) ethanesulfonic acid (MES$\mathrm{NaOH}$ ) buffer ( $\mathrm{pH}$ 6.2) and sterilized. The plugs were submerged in solutions and evacuated at $500 \mathrm{~mm} \mathrm{Hg}$ for $20 \mathrm{sec}$. MES buffer and water were compared in initial experiments and shown to have no significant effect on plug softening. The plug firmness was measured every $4 \mathrm{~h}$.

Individual plug ethylene production and respiration rates were measured every 4 hours for the first 12 or $16 \mathrm{~h}$ and at the end of the storage period $(24 \mathrm{~h})$. The cotton test tube covers were removed in a laminar flow hood and the tube was sealed with a rubber stopper. After $30 \mathrm{~min}, 2 \mathrm{ml}$ of gas was withdrawn. One milliliter of gas was analyzed for ethylene concentration and $1 \mathrm{ml}$ for $\mathrm{CO}_{2}$ concentration. Ethylene production was analyzed by a gas chromatograph fitted using an alumina column $(1.5 \mathrm{~m} \times 3 \mathrm{~mm})$ and photoionization detector. Carbon dioxide was measured with a flow-through infrared gas analyzer.

Mesocarp Ca fractionation. Mesocarp tissue Ca fractionation was done according to the procedure of Fcrguson et al. ( 1980). To avoid the variability of $\mathrm{Ca}$ content in different fruit, samples were taken from the same fruit at color break, $50 \%$, and $100 \%$ yellow stages. Six fruit were used and two duplicate samples were taken from each fruit at each ripening stage. The mesocarp tissue was taken with a sterile $1.4-\mathrm{cm}$ corkborer. The holes were immediately filled with sterile cotton and warm lanolin, and the fruit were returned to the storage room until they reached the next required ripening stage (Paull and Chen, 1983). The plug minus the skin and placenta was quickly frozen with liquid $\mathrm{N}$ and lyophilized. The dry mesocarp tissue was ground in a mortar and pestle in liquid $\mathrm{N}$ to very fine powder. The powder $(100 \mathrm{mg})$ was sequentially extracted with $3.5 \mathrm{ml} 80 \%$ acetic acid containing $10 \mathrm{~mm}$ cysteine and $5 \mathrm{ml}$ $0.25 \mathrm{M} \mathrm{HCl}$ containing $10 \mathrm{~mm}$ cysteine, with the residue being digested in $25 \mathrm{ml} 1 \mathrm{M} \mathrm{HCl}$. The sample was vigorously shaken during all extractions at $22 \mathrm{C}$. Calcium concentration in each fraction was measured by atomic absorption spectroscopy after addition of $\mathrm{LaCl}$.

\section{Results and Discussion}

Fruit fresh weight (Fig. 1A) had the greatest increase just before a plateau 80 days postanthesis, while the greatest increase in dry weight (Fig. 1B) occurred just before maturity, 130 days postanthesis. There were similar growth rates in fruit weight and volume (Fig. 1C) during both periods. The uptake of Ca (Fig. 1D), $\mathrm{Mg}$ (Fig. 1E), and K (Fig. 1F) by the whole fruit were similar, paralleling the increase in DW, but not FW. The uptake patterns of $\mathrm{Ca}, \mathrm{Mg}$, and $\mathrm{K}$ by the skin. mesocarp, and seeds were different from each other and also paralleled the rate of increase in DW. While mesocarp FW and DW increased $\approx 10$-fold, total $\mathrm{Ca}$ increased $\approx 4$-fold during growth. The highest mesocarp Ca uptake rate on a flesh weight basis occurred in fruit $<40$ days old (Table 1) and may be related to higher transpiration from the fruit surface at that time. The highest $\mathrm{Ca}$ uptake rate on a fruit basis occurred 80 to 140 days postanthesis.

The mean papaya fruit surface water diffusive resistance was $0.5 \mathrm{~s} \cdot \mathrm{cm}^{-1}$ when the papaya fruit were 60 days old and increased to $11.3 \mathrm{~s} \cdot \mathrm{cm}^{-1}$ when the fruit were 120 days old and to $18.6 \mathrm{~s} \cdot \mathrm{cm}^{-1}$ at 140 days old (data not shown), a 37-fold increase. Fruit surface transpiration is an important motive force for water and $\mathrm{Ca}$ ion flow into fruit (Bangerth, 1979; Ferguson and Watkins, 1989). As the proportion of water imported to tomato fruit via the xylem decreases and that via the phloem increases. fruit $\mathrm{Ca}$ accumulation rate also decreases (Ho et al., 1987). The competition between fruit and leaf for water may also reduce the $\mathrm{Ca}$ transport to the fruit. The high rate of papaya Ca uptake during the first 60 days postanthesis may therefore be partially associated with the higher rate of transpiration from the fruit surface and the lower surface area to weight ratio of the fruit.

Papaya mesocarp Ca uptake (Table 1) did not parallel mesocarp growth (Fig. 1A) suggesting that Ca uptake was not determined by fruit growth alone. Sucrose in papaya mesocarp increases $\approx 4$-fold, 110 to 140 days postanthesis (Chan et al., 1979), a period of steady 
Ca uptake (Table 1). High sucrose accumulation in mesocarp during this period reflects increased phloem importation or decreased osmotic potential, either or both of which could increase xylem water flow to the mesocarp. Alternatively, root pressure may also provide a certain amount of $\mathrm{Ca}$ to papaya fruit, as suggested for tomatoes (Banuelos et al., 1985). In addition, $\mathrm{Ca}$ import into tomato fruit is favored at night when the humidity is normally highest, although the rate of Ca absorption and translocation from root to shoot does not differ between the day and night (Tachibana, 1991).

Calcium concentration was lowest in the mesocarp (Fig. 1D) and was not significantly different among the peduncle, equatorial, and blossom regions (Table 2). However, Ca concentration was significantly higher in the outer mesocarp $\left(187 \mu \mathrm{g} \cdot \mathrm{g}^{-1} \mathrm{FW}\right)$ than the inner mesocarp $\left(127 \mu \mathrm{g} \cdot \mathrm{g}^{-1} \mathrm{FW}\right)$. In contrast, a longitudinal gradi-
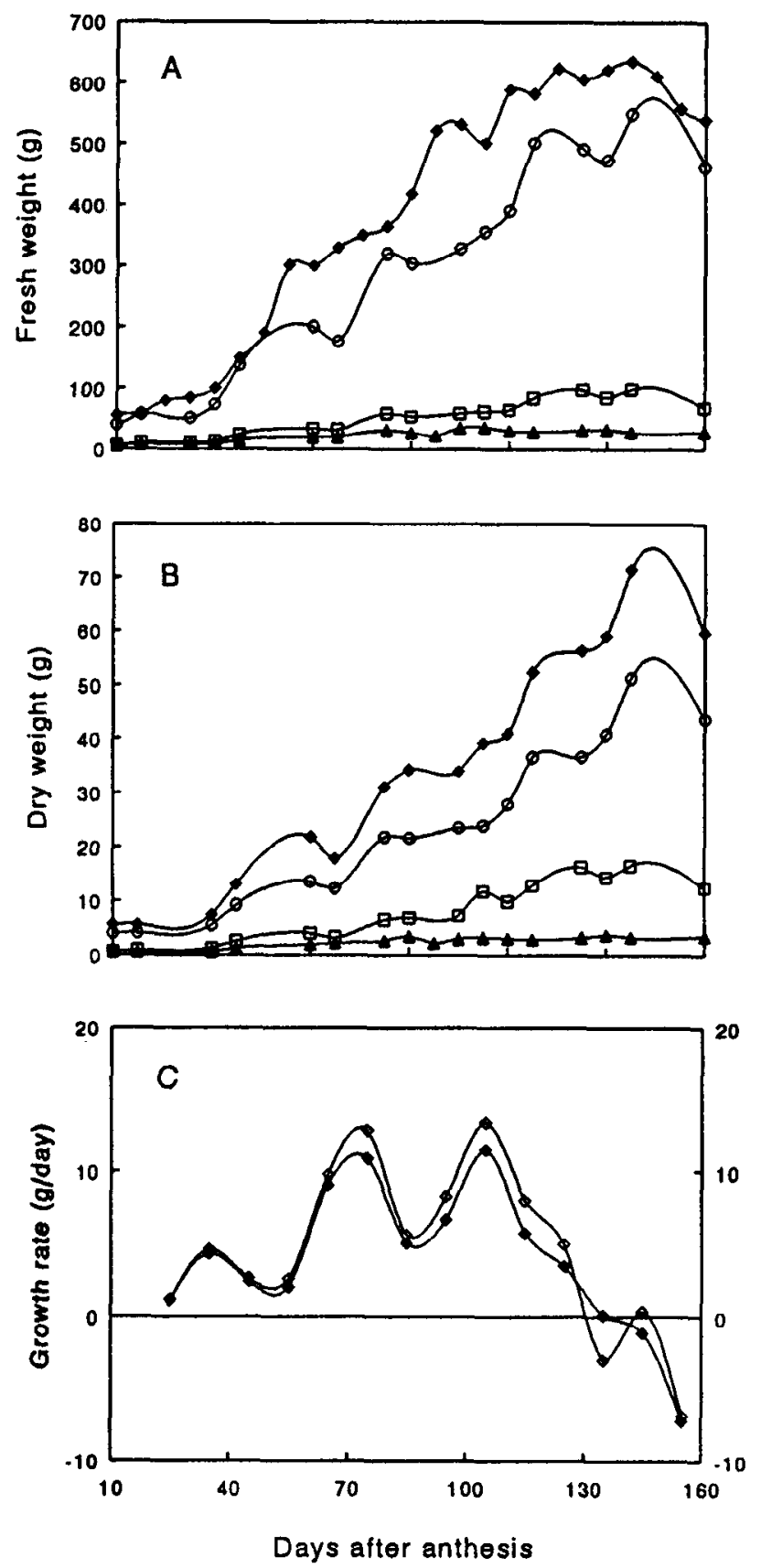

ent in $\mathrm{Ca}$ is found in avocado (Chaplin and Scott, 1980) and tomato (Ehret and Ho, 1986). The vascular network in tomato fruit has increased branching from the proximal to the distal half and a decline in the ratio of xylem to phloem area, increasing the resistance to xylem water movement leading to lower $\mathrm{Ca}$ content in the distal half (Ehret and Ho, 1986). The vascular bundles in papaya mesocarp extends longitudinally throughout the mesocarp and therefore may distribute Ca relatively evenly from the peduncle to the blossom end. The high levels of $\mathrm{K}$ at the peduncle (Table 2) may be related to the active sugar uptake via the phloem occurring in mature fruit (Chan et al., 1979). While the $\mathrm{Mg}$ distribution (Table 2) may be a function of the higher uptake 80 to 110 days postanthesis (Fig. 1E) and lower rate in mature fruit.

Spraying papaya fruit six times over 12 weeks with $\mathrm{CaCl}_{2}(2 \%$ w/v) during fruit growth and development did not significantly
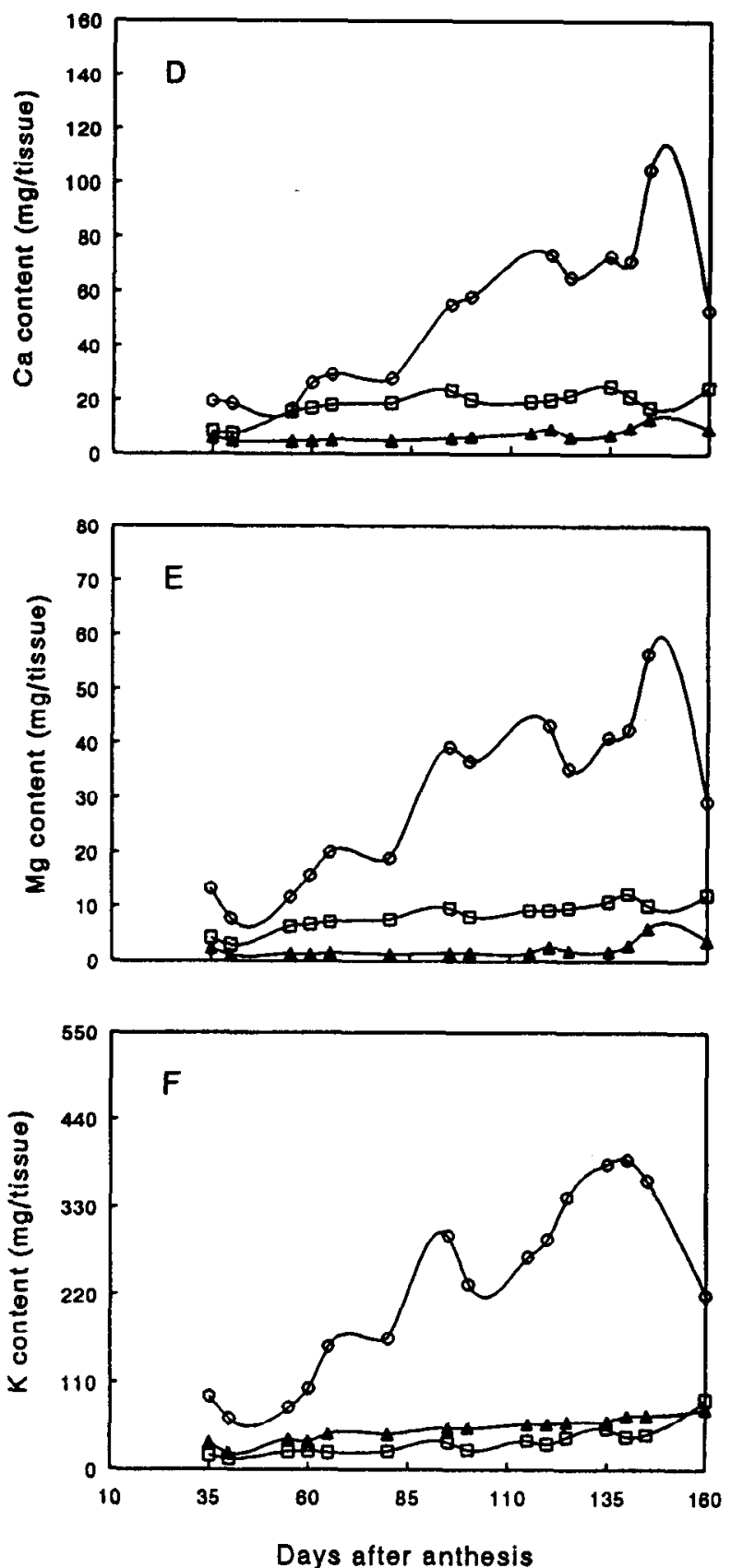

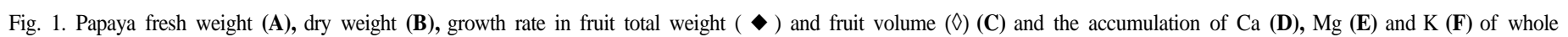
fruit $(\bullet)$, skin $(\boldsymbol{\Delta})$, mesocarp $(\bigcirc)$ and seed $(\square)$,during growth and development. Each data point mean $n=6$. 
Table 1. The changes in papaya fruit dry weight percentage and Ca concentration of mesocarp tissue during fruit growth and development.

\begin{tabular}{lccc}
\hline \hline $\begin{array}{l}\text { Days after } \\
\text { anthesis }\end{array}$ & $\begin{array}{c}\text { Dry wt } \\
(\%)\end{array}$ & $\begin{array}{c}\mathrm{C} \mathrm{a} \\
\left(\mu \mathrm{g} \cdot \mathrm{g}^{-1} \mathrm{~F} \mathrm{~W}^{y}\right)\end{array}$ & $\begin{array}{c}\mathrm{C} \mathrm{a} \\
\left(\mu \mathrm{g} \cdot \mathrm{g}^{-1} \mathrm{D} \mathrm{W}^{y}\right)\end{array}$ \\
\hline 30 & 8.9 & $405 \mathrm{a}$ & $4506 \mathrm{a}$ \\
60 & 7.7 & $256 \mathrm{~b}$ & $3340 \mathrm{ab}$ \\
80 & 6.9 & $135 \mathrm{c}$ & $1899 \mathrm{~b}$ \\
100 & 7.0 & $180 \mathrm{c}$ & $2511 \mathrm{~b}$ \\
120 & 7.1 & $163 \mathrm{c}$ & $2748 \mathrm{~b}$ \\
140 & 8.6 & $158 \mathrm{c}$ & $1677 \mathrm{~b}$
\end{tabular}

$\overline{\bar{T}}$ Data were analysed with Duncan's multiple range test and means with some letters in the same column were not significantly different at $5 \%$ level, $\mathrm{n}=6$.

${ }^{y} \mathrm{FW}=$ fresh weight.

${ }^{\mathrm{x}} \mathrm{DW}=$ dry weight.

Table 2. Longitudinal distribution of $\mathrm{Ca}, \mathrm{Mg}$, and $\mathrm{K}$ in papaya mesocarp from fruit at the $10 \%$ yellow stage.

\begin{tabular}{llrr}
\hline \hline & & Content $\left(\mu \mathrm{g} \cdot \mathrm{g}^{-1} \text { fresh } w \mathrm{t}\right)^{2}$ & $\mathrm{~K}$ \\
\cline { 2 - 4 } Position & $\mathrm{C} \mathrm{a}$ & $\mathrm{M} \mathrm{g}$ & $3084 \mathrm{a}$ \\
\hline Peduncle end & $143 \mathrm{a}$ & $92 \mathrm{c}$ & $1221 \mathrm{~b}$ \\
Equatorial zone & $117 \mathrm{a}$ & $202 \mathrm{a}$ & $1213 \mathrm{~b}$ \\
Blossom end & $133 \mathrm{a}$ & $143 \mathrm{~b}$ & $\mathrm{~b}$
\end{tabular}

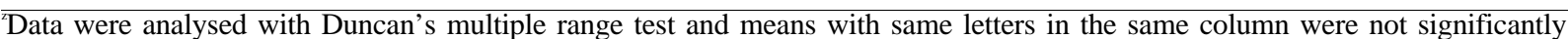
different at $5 \%$ level. $\mathrm{n}=5$.

Table 3. Effect of fertilization on $\mathrm{Ca}, \mathrm{Mg}$, and $\mathrm{K}$ in papaya leaf petiole and mesocarp from color break fruit.

\begin{tabular}{|c|c|c|c|c|c|c|}
\hline \multirow[b]{3}{*}{ Fertilization } & \multicolumn{6}{|c|}{ Mineral content of } \\
\hline & \multicolumn{3}{|c|}{ Petiole $(\% \text { dry } w t)^{2}$} & \multicolumn{3}{|c|}{ Fruit mesocarp $\left(\mu \mathrm{g} \cdot \mathrm{g}^{-1}\right.$ Fresh $\left.\mathrm{wt}\right)$} \\
\hline & $\mathrm{Ca}$ & $\mathrm{Mg}$ & K & $\mathrm{Ca}$ & $\mathrm{Mg}$ & K \\
\hline Control & $0.98 \mathrm{bc}$ & $0.65 \mathrm{a}$ & $1.89 \mathrm{~b}$ & $138 \mathrm{~b}$ & $119 \mathrm{a}$ & $1070 \mathrm{~b}$ \\
\hline $\mathrm{Ca}$ & $1.29 \mathrm{a}$ & $0.47 \mathrm{~b}$ & $1.93 \mathrm{~b}$ & $145 \mathrm{a}$ & $180 \mathrm{~b}$ & $1095 \mathrm{~b}$ \\
\hline $\mathrm{Ca}+\mathrm{K}$ & $1.15 \mathrm{ab}$ & $0.29 \mathrm{c}$ & $3.80 \mathrm{a}$ & $151 \mathrm{a}$ & $197 \mathrm{a}$ & 1518 a \\
\hline $\mathrm{K}$ & $0.84 \mathrm{c}$ & $0.41 \mathrm{bc}$ & $3.74 \mathrm{a}$ & $120 \mathrm{~d}$ & $186 \mathrm{~b}$ & $1497 \mathrm{a}$ \\
\hline $\mathrm{N}$ & $0.99 \mathrm{bc}$ & $0.76 \mathrm{a}$ & $1.21 \mathrm{c}$ & $130 \mathrm{c}$ & $182 \mathrm{~b}$ & $904 \mathrm{c}$ \\
\hline
\end{tabular}

$\overline{\overline{ }}$ Data were analyzed with Duncan's multiple range test and means with same letters in the same column were not significantly different at $5 \%$ level. $\mathrm{n}=165$.

increase the mesocarp Ca level (data not shown) such as occurs with sprayed apple fruit (Glenn et al., 1985). Lenticels, cracks, or other surface irregularities arc the important pathway of Ca diffusion through the cuticle in fruit such as apple (Glenn et al., 1985): in the papaya, lenticels are absent and stomata of mature fruit arc apparently blocked by wax (Paull and Chen, 1980). The cuticle of papaya, although not well developed in immature fruit (Sanxter. 1989). increases in thickness from 15 to $50 \mu \mathrm{m}$ during fruit growth and development (Quintana and Paull, 1993). Papaya cuticle thickness is almost twice that of apples (Glenn et al., 1985) and may be a more effective barrier to cuticle absorption.

Vacuum infiltration of $\mathrm{Ca}$ into papaya was unsuccessful (data not shown) using similar conditions reported to increase $\mathrm{Ca}$ in apple tissue by $70 \%$ (Fcrguson and Watkins, 1989). Water soluble flowerdye was vacuum infiltrated only 1 to $2 \mathrm{~mm}$ into papaya fruit. Attempts to draw $\mathrm{Ca}$ into the mesocarp via the peduncle using transpiration were also unsuccessful in uniformly increasing mesocarp $\mathrm{Ca}$. Either transpiration by detached mature fruit was not an effective motive force or the peduncle vascular bundle may have become wholly or partially blocked during the 48-h treatment.

Calcium fertilizer treatment significantly increased $\mathrm{Ca}$ concentration in fruit and leaf petioles (Table 3) above the control.
Calcium soil fertilization also did not always increase mesocarp $\mathrm{Ca}$ concentration. The higher mesocarp $\mathrm{Ca}$ concentration in all fertilizer treatment of fruit harvested in April (Fig. 2) may be related to the high rainfall during January to February when the fruit were young. There was an overall increase in mesocarp Ca concentration (Fig. 2) hut a decrease in Mg concentration in all fertilizer treatment throughout the year. Mesocarp $\mathrm{K}$ did not significantly change throughout the year of sampling. Both $\mathrm{N}$ and $\mathrm{K}$ fertilizer treatments significantly decreased mesocarp $\mathrm{Ca}$ concentration (Table 3). Calcium uptake by papaya plants and fruit may therefore be influenced by temperature. relative humidity. levels of other minerals in the soil. and plant age as for other crops (Clarkson. 1984: Shear. 1975).

Potassium fertilization reduced the $\mathrm{Ca}$ concentration in leaf petioles and fruit mecocarp (Table 3 ). This agrees with the finding that $\mathrm{K}$ fertilization decreased leaf petiole $\mathrm{Ca}$ concentration (Awada and Long. 1971: Awada et al.. 1986). Calcium fertilization did not affect the $\mathrm{K}$ concentration in leaf petiole and the fruit mesocarp (Table 3). while Ca plus $\mathrm{K}$ fertilization increased mesocarp $\mathrm{Ca}$ (Table 3). Since the application of $\mathrm{K}$ fertilizer to papaya plants increases mesocarp total soluble solids (Awada and Long. 1971). it is possible that increases in mesocarp $\mathrm{K}$ and sugars may reduce 


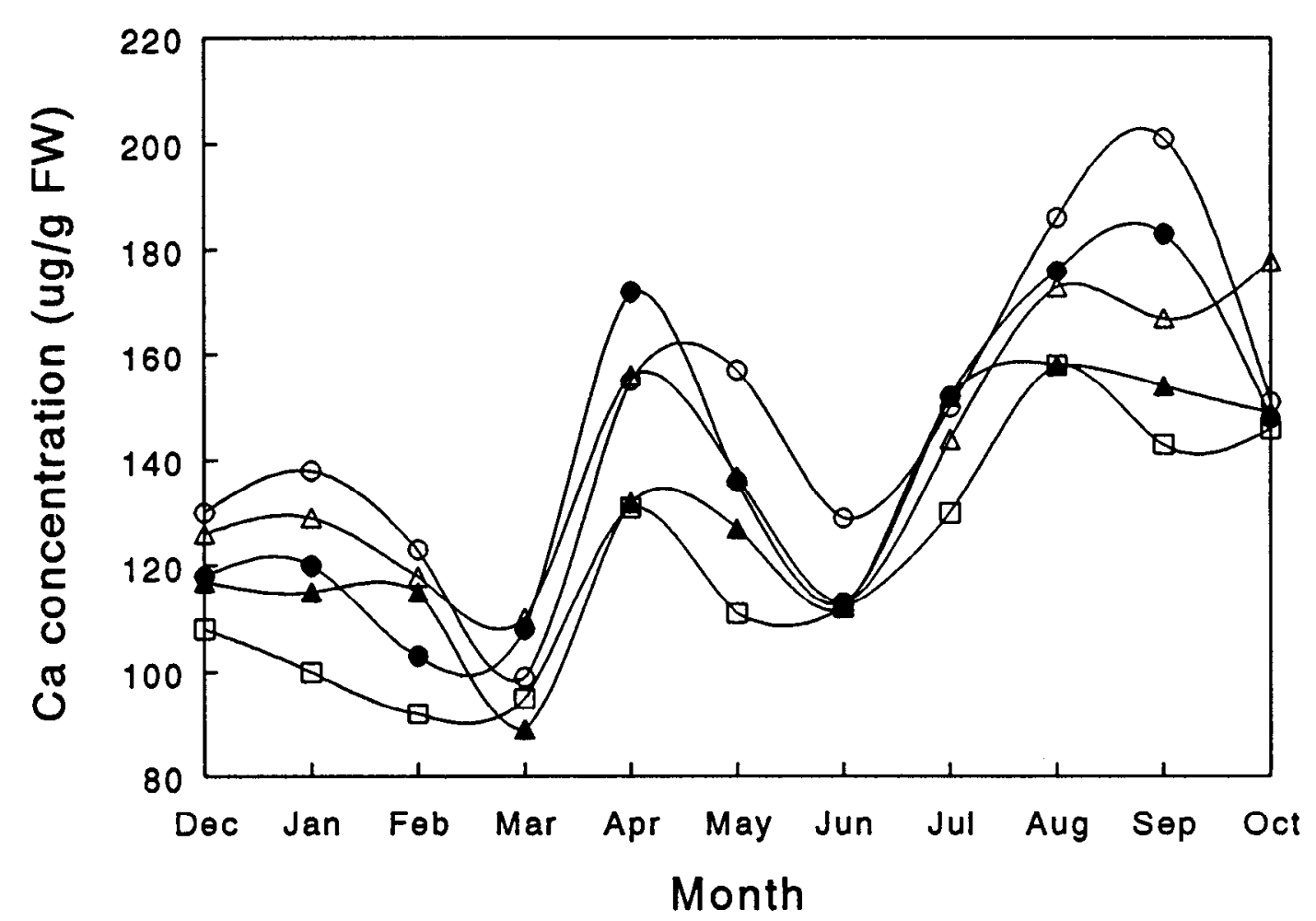

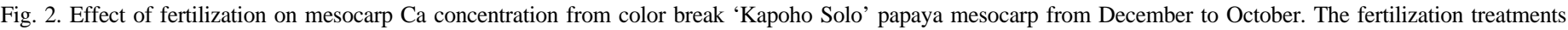
were control $(\bigcirc), \mathrm{Ca}(\Delta)$, Ca plus $\mathrm{K}(\bigcirc), \mathrm{K}(\square)$ and $\mathrm{N}(\boldsymbol{\Delta})$. Analysis of variance: month***, Ca***, month $\times \mathrm{Ca}{ }^{* * *}, \mathrm{n}=16$; $* * *$ Significant at $P \leq 0.001$

the fruit water potential, resulting in water and Ca movement into the mesocarp. There is a strong association between high $\mathrm{N}$ fertilization and $\mathrm{Ca}$ deficiency disorders in apple fruit (Ferguson and Watkins, 1989; Shear, 1975); this suggests that high $\mathrm{N}$ fertilization could induce $\mathrm{Ca}$ deficiency in papaya fruit. However, high $\mathrm{N}$ fertilization of papaya tended to delay ripening (Table 4) and had no effect on papaya leaf petiole Ca concentration, but decreased mesocarp Ca concentration.

No fertilizer treatment, except for $\mathrm{N}$, had a significant effect on fruit skin color and mesocarp color development (Table 4). The $\mathrm{N}$ treatment significantly delayed skin and mesocarp color development. Although Ca fertilizer treatment did not always increase the firmness of the ripe fruit in the monthly harvests, $\mathrm{Ca}$ and $\mathrm{Ca}$ plus $\mathrm{K}$ fertilizer treatments significantly increased fruit firmness with an average deformation force of 76 and $78 \mathrm{~N}$, respectively, vs. 68 $\mathrm{N}$ in the control treatment (Table 4). Potassium treatment had no significant effect on fruit firmness $(69 \mathrm{~N})$, while fruit from the $\mathrm{N}$ fertilizer plots were firmer $(81 \mathrm{~N})$ than control fruit $(68 \mathrm{~N})$ (Table 4).

Papaya mesocarp Ca concentration in the mesocarp was posi- tively correlated with ripe papaya fruit firmness (Table 5). Other fruit with natural or artificially raised higher $\mathrm{Ca}$ concentration also show positive correlations between $\mathrm{Ca}$ concentration and fruit firmness and ripening rate of apple (Abbott et al., 1989; Conway and Sams, 1987; Poovaiah et al., 1988), cherry (Facteau et al., 1987), and avocados (Tingwa and Young, 1974). The positive correlation between Ca concentration and ripe fruit firmness was described by the significant quadratic and cubic (firmness ratio $=$ $\left.-2.707+0.071 \mathrm{Ca}-0.0004 \mathrm{Ca}^{2}+0.0000008 \mathrm{Ca}^{3}\right)$ regression equation (Table 5). The development of skin and mesocarp color during fruit ripening was significantly delayed (Table 4), and fruit softening was significantly slower in fruit from the $\mathrm{N}$ treatment. The June data did not follow the same trends as other monthly data. If the data from the $\mathrm{N}$ treatment and June data were removed, the significance increasedin the cubic (firmness ratio $=-2.780+0.069 \mathrm{Ca}-0.0004 \mathrm{Ca}^{3}$ $+0.0000007 \mathrm{Ca}^{3}$ ) regression equation (Table 5).

When mesocarp Ca concentration was $130 \mu \mathrm{g} \cdot \mathrm{g}^{-1} \mathrm{FW}(\approx 1.3$ $\mathrm{mg} \cdot \mathrm{g}^{-1} \mathrm{DW}$ ) or greater, fruit softened at a slower rate than fruit with lower concentrations (Fig. 3). Fruit with $<130 \mu \mathrm{g} \cdot \mathrm{g}^{-1} \mathrm{FW}$ Ca could

Table 4. Effects of field fertilization on papaya fruit ripening. Results are means of 11 monthly harvests. Fruit were ripened at $25 \mathrm{C}$ until the skin color of most fruit in the control treatment had reached $\approx 85 \%$ yellow.

\begin{tabular}{|c|c|c|c|c|c|}
\hline Treatment & $\begin{array}{c}\text { Initial } \\
\text { skin color } \\
(\%)\end{array}$ & $\begin{array}{c}\text { Final } \\
\text { skin color } \\
(\%)\end{array}$ & $\begin{array}{c}\text { Final } \\
\text { mesocarp } \\
\text { color }\end{array}$ & $\begin{array}{l}\text { Deformation } \\
\text { force } \\
\text { (N) }\end{array}$ & $\begin{array}{c}\text { Firmness } \\
\text { ratio }^{y}\end{array}$ \\
\hline Control & $7 a$ & $89 \mathrm{a}$ & $96 \mathrm{ab}$ & $68 \mathrm{~b}$ & -- \\
\hline $\mathrm{Ca}$ & $4 \mathrm{~b}$ & $86 \mathrm{a}$ & $95 \mathrm{~b}$ & $76 \mathrm{a}$ & 1.13 \\
\hline $\mathrm{Ca}+\mathrm{K}$ & $4 \mathrm{~b}$ & $86 \mathrm{a}$ & $95 \mathrm{~b}$ & $78 \mathrm{a}$ & 1.16 \\
\hline K & $5 \mathrm{~b}$ & 88 a & $97 \mathrm{a}$ & $69 \mathrm{~b}$ & 1.02 \\
\hline $\mathrm{N}$ & $3 \mathrm{~b}$ & $80 \mathrm{~b}$ & $91 \mathrm{c}$ & $81 \mathrm{a}$ & 1.20 \\
\hline
\end{tabular}

$\overline{{ }^{2}}$ Data were analyzed with Duncan's multiple range test and means with same letters in the same column were not significantly different at $5 \%$ level. $\mathrm{n}=220$.

${ }^{y}$ Firmness ratio $=$ firmness of the treatment/firmness of control treatment. 


\begin{tabular}{llc}
\hline & \multicolumn{1}{c}{ Coefficient of determination } \\
\cline { 2 - 3 } Repression model $^{y}$ & -N and June data \\
\hline Firmness ratio $=\mathrm{a}+\mathrm{bCa}+\mathrm{cCa}+\mathrm{dCa}^{3}$ & 0.429 & $0.386^{* *}$ \\
Firmness ratio $=\mathrm{a}+\mathrm{b}(\mathrm{Ca} / \mathrm{Mg})+\mathrm{c}(\mathrm{Ca} / \mathrm{Mg})^{2}+\mathrm{d}(\mathrm{Ca} / \mathrm{Mg})^{3}$ & $0.255^{*}$ & 0.160 \\
Firmness ratio $=\mathrm{a}+\mathrm{b}(\mathrm{Ca} / \mathrm{K})+\mathrm{c}(\mathrm{Ca} / \mathrm{K})^{2}+\mathrm{d}(\mathrm{Ca} / \mathrm{K})^{3}$ & $0.260^{*}$ & $0.060^{\mathrm{Ns}}$ \\
Firmness ratio $=\mathrm{a}+\mathrm{b}[\mathrm{Ca} /(\mathrm{Mg}+\mathrm{K})]+\mathrm{c}(\mathrm{Ca} /(\mathrm{Mg}+\mathrm{K})]^{2}+\mathrm{d}[\mathrm{Ca} /(\mathrm{Mg}+\mathrm{K})]^{3}$ & $0.177^{*}$ \\
\hline
\end{tabular}

${ }^{\overline{2}}$ Data were analyzed by the procedures of general linear model and nonlinear curve fitting model.

${ }^{y}$ Firmness ratio $=$ firmness of treatment/fimmness of control treatment.

${ }^{\mathrm{Ns}}, *, * * * * *$ Nonsignificant or significant at $P=0.5$. 0.1 . or 0.01 . respectively: $\mathrm{n}=20$.

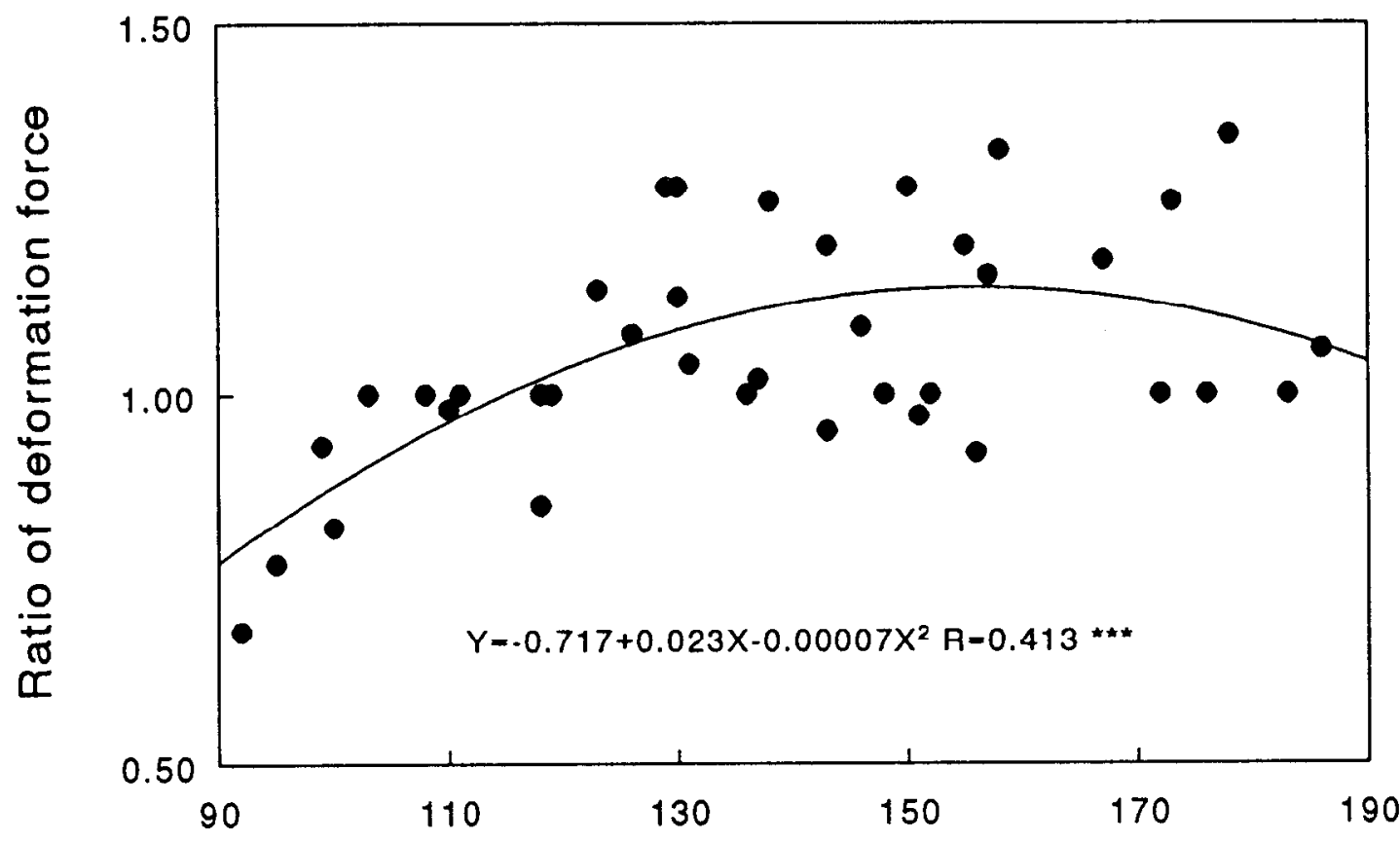

\section{Ca concentration (ug/g FW)}

Fig. 3. Relationship between mesocarp Ca concentration and ratio between deformation force at full ripe stage for Ca-fertilized fruit and non Ca fertilized fruit.

therefore be expected to be susceptible to the soft fruit disorder reported for papaya (Paull, 1987). The critical Ca concentration for papaya $\left(1.3 \mathrm{mg} \cdot \mathrm{g}^{-1} \mathrm{DW}\right)$ contrasts with the concentration $(0.4$ $\left.\mathrm{mg} \cdot \mathrm{g}^{-1} \mathrm{DW}\right)$ required to eliminate the development of tissue breakdown found in tipburn of lettuce (Barta and Tibbitts. 1991), tomato blossom-end rot (Cerda et al., 1979). and bitter pit of apple (Ferguson and Watkins, 1989). No correlation was found between ripe papaya fruit firmness and $\mathrm{Mg}$ or $\mathrm{K}$ concentration (data not shown). There were significant correlations between papaya fruit firmness and the ratio of $\mathrm{Ca}$ to $\mathrm{K}$ or $\mathrm{Mg}$ concentration. or to $\mathrm{Mg}$ plus $\mathrm{K}$ concentrations (Table 5). The involvement of $\mathrm{K}$ or $\mathrm{Mg}$ appeared to be related to $\mathrm{Ca}$ concentration, rather than an effect of these minerals per se.

The processes characteristic of ripening in intact fruit arc basically duplicated in excised pericarp discs or plugs from tomato (Campbell et al., 1\%)). The ripening pattern of excised papaya mesocarp plugs although X-fold faster is similar to that of intact fruit. The plugs could therefore be a model to study the effect of $\mathrm{Ca}$ on mesocarp ripening (Qiu, 1992). Infiltration of plugs with $\mathrm{CaCl}_{2}$, sodium citrate, and EGTA had no significant effect on mesocarp plug respiration from $10 \%$ yellow fruit (Fig. 4A). The pattern of ethylene production in mcsocarp plugs (Fig. 4B) was about the same for the control and $\mathrm{CaCl}_{2}$-treated plugs. although $50 \%$ reduced by the Ca treatment. EGTA treatment doubled ethylene production, while sodium citrate reduced ethylene production. Calcium concentration in the mesocarp tissue increased $\approx 100 \%$ when plugs were infiltrated with $50 \mathrm{mM} \mathrm{CaCl}_{2}$ and was more effective in reducing softening rate in plugs from color break and $10 \%$ yellow fruit (Fig. 4C) than in plugs from $30 \%$ and $50 \%$ yellow fruit (Fig. 4D). EGTA and sodium citrate infiltration increased the softening rate $8 \mathrm{~h}$ after treatment in plugs from $10 \%$ and $50 \%$ yellow fruit. In fruit that contain high levels of cell wall- and middle lamella-bound $\mathrm{Ca}$, removal of $\mathrm{Ca}^{++}$from pericarp tissue or from recovered cell walls by chelating agents. such as EDTA or citrate, may promote extensive hydrolysis of the pectin molecules (Brady et al.. 1985; Buescher and Hobson. 1982). Infiltration of papaya mesocarp plugs with $\mathrm{MgCl}_{2}$ and $\mathrm{KCl}$ did not increase tissuc firmness or rate of plug softening: Infiltration with $\mathrm{Mg}$ in intact apple fruit (Conway and Sams, 1987) as well as in excised tissue (Stow. 1989) increases the firmness of apples or the fruit tissue to a lesser extent than $\mathrm{Ca}$. The difference in part could be ascribed to papaya having already begun to ripen when treated.

The fractionation of $\mathrm{Ca}$ in papaya mesocarp tissue from color break, $50 \%$ and $100 \%$ yellow fruit indicated that most $\mathrm{Ca}$ was in the $80 \%$ acetic acid fraction with 10 to $16 \%$ in the $0.25 \mathrm{~N} \mathrm{HCl}$ and $<1 \%$ in the $1 \mathrm{~N} \mathrm{HCl}$ fraction. This distribution suggests that most 

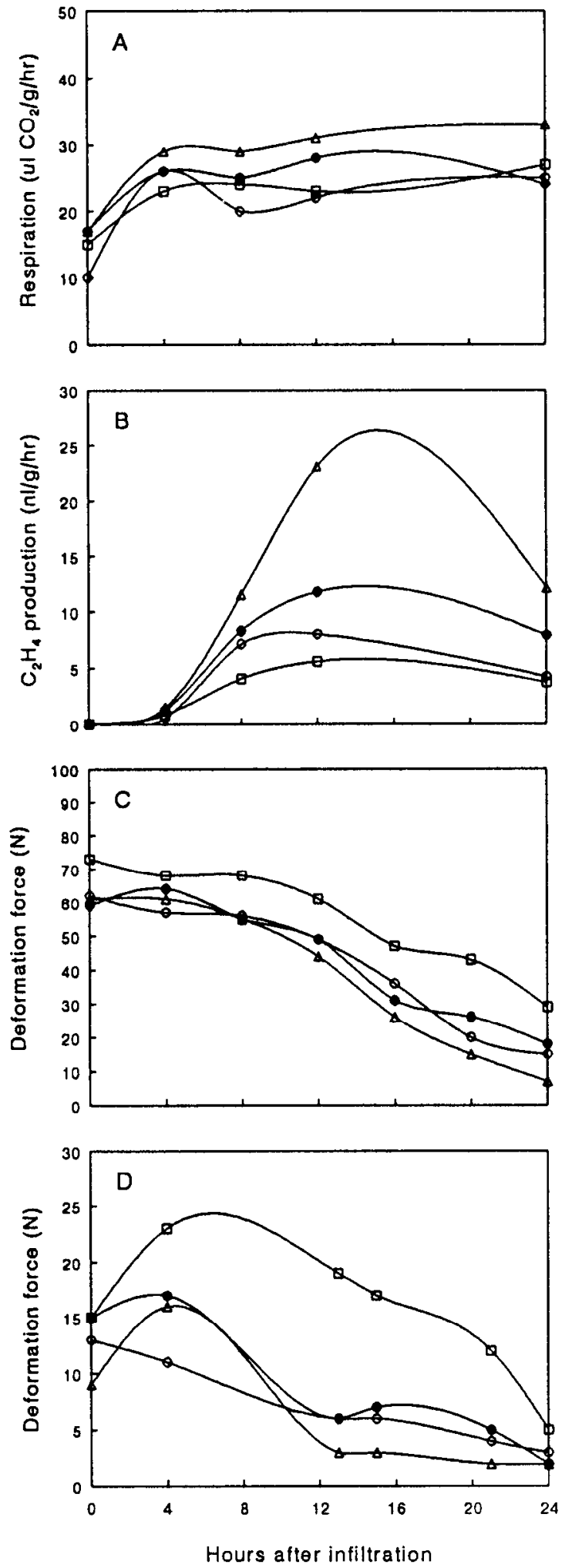

Fig. 4. Effect of $\mathrm{CaCl}_{2}$ and $\mathrm{Ca}$ chelators infiltrated in papaya mesocarp plugs from $10 \%$ yellow fruit, on respiration (A) and ethylene production (B). and deformation force on plugs from $10 \%$ (C) and 50\% (D) yellow fruit. The treatments were control ( $) .10$ mm EGTA $(\Delta) .25 \mathrm{~mm}$ sodium citrate $(\mathrm{O})$ and $50 \mathrm{~mm} \mathrm{CaCl}_{2}(\square)$. Analysis of variance: respiration, treatment ${ }^{\mathrm{Ns}}$, hour***, treatment $\times$ hour**; ethylene production, treatment', hours". treatment $\times$ hours": deformation force. $10 \%$ yellow, treatment", hour"', treatment $\times$ hour***; deformation force $0,50 \%$ yellow, treatment'. hour", treatment $\times$ hours ${ }^{\mathrm{Ns}},{ }^{\mathrm{Ns}}, * *, * * *$ Nonsignificant or Significant at $P \leq 0.05, \leq 0.01, \leq 0.001 ; \mathrm{n}=10$. of the $\mathrm{Ca}$ in mesocarp tissue was bound to pectin in the cell wall (Ferguson et al.. 1980). It has been suggested that fruit softening occurs either by movement of $\mathrm{Ca}^{2+}$ from the middle lamella or by the loss of $\mathrm{Ca}^{2+}$ attachment sites (Knee and Hartley, 1981). That the Ca concentration in $80 \%$ acetic acid fraction did not changeduring papaya ripening. suggests that the Ca probably stayed in the cell wall. Some loss of $\mathrm{Ca}^{2+}$ cell wall attachment sites may have occurred during papaya ripening as the Ca contents in the $0.25 \mathrm{M}$ and $1 \mathrm{M} \mathrm{HCl}$ fractions decreased during ripening.

Calcium concentration in papaya fruit varied significantly with harvest date. There were two periods during fruit growth when there was significant movement of $\mathrm{Ca}$ into fruit. and these periods relate in part to $\mathrm{FW}$ and DW changes during fruit growth. Fruit mesocarp $\mathrm{Ca}$ concentration was related to the rate of softening during papaya fruit ripening. Fruit whose mesocarp Ca concentration was $>130 \mu \mathrm{g} \cdot \mathrm{g}^{-1} \mathrm{FW}$ would not be expected to be susceptible to the soft fruit condition reported by commercial shippers and handlers. However, fruit with mesocarp Ca concentration <130 $\mu \mathrm{g} \cdot \mathrm{g}^{-1} \mathrm{FW}$ could be anticipated to occur a number of times during a year. Low mesocarp $\mathrm{Ca}$ uptake was related to preharvest environmental conditions and fertilization.

\section{Literature Cited}

Abbott, J.A., W.S. Conway, and C.E. Sams. 1989. Postharvest Cachloride infiltration affects textural attributes of apple. J. Amer. Soc. Hort. Sci. 114:932-936.

Awada, M. and C. Long. 1971. The selection of the potassium index in papaya tissue analysis. J. Amer. Soc. Hort. Sci. 96:74-77.

Awada, M., R.S. de la Pena, and R.H. Suehisa. 1986. Effects of nitrogen and potassium fertilization on growth, fruiting. and petiole composition of bearing papaya plants. College of Tropical Agriculture and Human Resources. Univ. of Hawaii. Res. Ser. 043.

Bangerth, F. 1979. Calcium-related physiological disorders of plants. Annu. Rev. Phytopathol. 17:97-122.

Banuelos, G.S.. G.P. Offermann, and E.C. Seim. 1985. High relative humidity promotes blossom-end rot on growing tomato fruit. HortScience 20:894-895.

Barta, D.J. and T.W Tibbitts. 1991. Calcium localization in lettuce leaves with and without tipburn: comparison of controlled-environment and field-grown plants. J. Amer. Soc. Hort. Sci. 116:870-875.

Brady, C.J.. W.B. McGlasson, J.A. Pearson, S.K. Meldrum, and E. Kopeliovitch. 1985. Interactions between the amount and molecular forms of polygalacturonase, calcium. and firmness in tomato fruit. J. Amer. Soc. Hort. Sci. 110:254-258.

Buescher, R.W. and G.E. Hobson. 1982. Role of calcium and chelating agents in regulating the degradation of tomato fruit tissue by polygalacturonase. J. Food Biochem. 6:147-160.

Campbell, A.D., M. Huysamer, H.U. Stotz, L.C. Greve,and J.M.Labavitch. 1990. Comparison of ripening processes in intact tomato fruit and excised pericarp discs. Plant Physiol. 94: 1582-1589.

Cappellini. R.A.. M.J. Ceponis, and G.W. Lightner. 1988. Disorders in apricot and papaya shipments to the New York market. 1972-1985. Plant Dis. 72:366-368.

Cerda, A., F.T. Bangham, and C.K. Labanauskas. 1979. Blosson-end rot of tomato fruit as influence by osmotic potential and phosphorous of nutrient solution media. J. Amer. Soc. Hort. Sci. 104:236-239.

Chan, H.T., K.L. Hibbard, T. Goo, and E.K. Akamine. 1979. Sugar composition of papayas during fruit development. HortScience 14:140 141.

Chaplin, G.R. and K.J. Scott. 1980. Association of calcium in chilling injury susceptibility of stored avocados. HortScience 15:514-515.

Cheour, F., C. Willemot. J. Arul, J. Makhlouf, and Y. Desjardins. 1991. Postharvest response of two strawberry cultivars to foliar application of $\mathrm{CaCl}_{2}$. HortScience 25:1186-1188.

Clarkson, D.T. 1984. Calcium transport between tissue and its distribution in the plant. Plant Cell Environ. 7:449-456 
Conway, W.S. and C.E. Sams. 1987. The effects of postharvest infiltration ofcalcium, magnesium, or strontium on decay, firmness, respiration and ethylene production in apples. J. Amer. Soc. Hort. Sci. 112:300-303.

Eaks, I.L. 1985. Effects of calcium on ripening, respiration rate, ethylene production and quality of avocado fruit. J. Amer. Soc. Hort. Sci. $110.145-148$

Ehret, D.L. and L.C. Ho 1986. Translocation of calcium in relation to tomato fruit growth. Ann. Bot. 58:679-688.

Evans, H.J. and R.V. Troxler, 1953. Relation of calcium nutrition to the incidence of blossom-end rot in tomatoes. Proc. Amer. Soc. Hort. Sci. 61:316-352.

Facteau, T.J., K.E. Rowe. and N.E. Chestnut. 1987. Response of 'Bing' and 'Lambert sweet cherry fruit to preharvest calcium chloride applications. HortScience 72:271-273.

Ferguson, I.B. and C.B. Watkins. 1989. Bitter pit in apple fruit. Hort. Rev. 11:289-355.

Ferguson, I.B., N.A. Turner and E.G. Bollard. 1980. Problems in fractionating calcium in plant tissue. J. Sci. Food. Agr. 31:7-14.

Glenn, G.M.. B.W. Poovaiah, and H.P. Rasmussen. 1985. Pathway of calcium penetration through isolated cuticles of 'Golden Delicious' apple fruit. J. Amer. Soc. Hort. Sci. 110:166-171.

Ho, L.C.. R.I. Grange, and A.J. Pichen. 1987. An analysis of the accumulation of water and dry matter in tomato fruit. Plant Cell Environ. 10:157-162.

Knee, M. and I.M. Bartley. 1981. Composition and metabolism of cell wall polysaccharides in ripening fruits. In: J. Friend and M.J.C. Rhodes (eds.). Recent advances in biochemistry of fruits and vegetables. Academic Press, London. p. 133-148.

Paull, R.E. 1987. Papaya fruit ripening and quality. Proc. 3rd Annu. Hawaii Papaya Ind. Assn. Conf. p. 40-42.

Paull, R.E. and N.J. Chen. 1983. Postharvest variation in cell wall degrading enzymes of papaya (Carica papaya L.) during fruit ripening. Plant Physiol. 72:382-385.

Paull, R.E. and N.J. Chen. 1989. Waxing and plastic wraps influence water loss from papaya fruit during storage and ripening. J. Amer. Soc. Hort. Sci. 114:937-942.

Poovaiah, B.W. 1986. Role ofcalcium in prolonging storage life of fruits and vegetables. Food Technol. 40:86-89.

Poovaiah, B.W., G.M. Glenn. and A.S.N. Reddy. 1988. Calcium and fruit softening: Physiology and biochemistry. Hort. Rev. 10:107-143.

Qiu, Y.X. 1992. Theeffect of calcium on papaya fruit softening. $\mathrm{PhD}$ diss. Univ. of Hawaii, Honolulu (Abst. Int. 53:6073B-6074B).

Quintana, M.E.G. and R.E. Paull. 1993. Mechanical injury during postharvest handling of 'Solo' papaya fruit. J. Amer. Soc. Hort. Sci. 118:618-622.

Rigney, C.J. and R.B.H. Wills. 1981 Calcium movement, a regulating factor in the initiation of tomato fruit ripening. HortScience 16:550-551,

Sanxter, S.S. 1989. Ontogeny and senescence of photosynthetic activity in the exocarp of Carica papaya L. MS thesis. Univ. of Hawaii.

Shear, C.B. 1975. Calcium related disorders of fruits and vegetables. HortScience. 10:361-365.

Stow, J. 1989. The involvement of calcium ions in maintenance of apple fruit tissue structure. J. Expt. Bot. 40:1053-1057.

Tachihana, S. 1991. Import of calcium by tomato fruit in relation todaynight periodicity. Sci. Hort. 45:235-243.

Tingwa, P.D. and R.E. Young. 1074. The effect of calcium on the ripening of avocado (Persea americana Mill.) fruits. J. Amer. Soc. Hort. Sci. 99:5540-542.

Tirmazi, S.I.H. and R.B.H. Wills. 1981. Retardation of ripening of mangoes by postharvest application ofcalcium. Trop. Agr. 58:137-139.

Wills, R.B.H., S.I.H. Tiramazi, and K.J. Scott. 1982. Effect of postharvest application of calcium on ripening rates of pears and bananas. J. Hort. Sci. 57:431-435. 